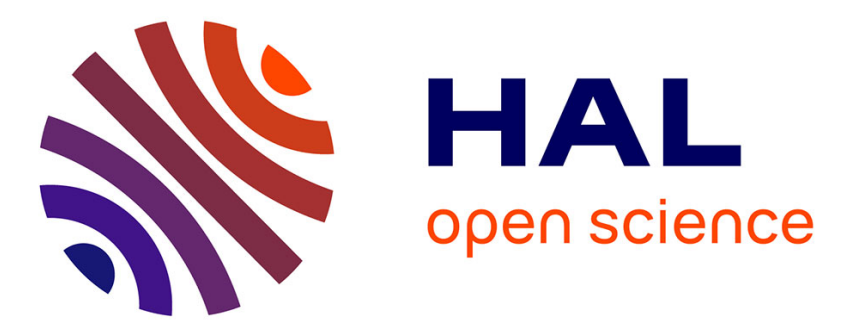

\title{
Low-energy laser radiation in correction of gastric precancer. Medical and biological effects
}

\author{
A. Karpov, V. Udut, V. Prokopjev, E. Savina, M. Yalova
}

\section{To cite this version:}

A. Karpov, V. Udut, V. Prokopjev, E. Savina, M. Yalova. Low-energy laser radiation in correction of gastric precancer. Medical and biological effects. Journal de Physique IV Proceedings, 1994, 04 (C4), pp.C4-215-C4-217. 10.1051/jp4:1994451 . jpa-00252714

\section{HAL Id: jpa-00252714 https://hal.science/jpa-00252714}

Submitted on 1 Jan 1994

HAL is a multi-disciplinary open access archive for the deposit and dissemination of scientific research documents, whether they are published or not. The documents may come from teaching and research institutions in France or abroad, or from public or private research centers.
L'archive ouverte pluridisciplinaire HAL, est destinée au dépôt et à la diffusion de documents scientifiques de niveau recherche, publiés ou non, émanant des établissements d'enseignement et de recherche français ou étrangers, des laboratoires publics ou privés. 


\title{
Low-energy laser radiation in correction of gastric precancer. Medical and biological effects
}

\author{
A.B. KARPOV, V.V. UDUT, V.E. PROKOPJEV, E.V. SAVINA and M.F. YALOVA
}

Research Institute of Pharmacology et Oncology, Tomsk Research, Center of Academy of Medical Sciences of Russia, Russia

The use of laser radiation of middle and high power finds an application for surgical and oncological practice. It is important for us to use laser radiation in cancer therapy-photodynamic therapy. This method is based on the selective accumulation of endo- and exogenous porphyrins by malignant tissues [3]. Tissues with dysplasia have the same ability to accumulate porphyrin connectious [1]. We consider it to be possible to use the low-energy laser radiation in therapy of such tissue transformations which are precancer ones.

Stomach ulcer with mucosa dysplasia has a high potence to the malignant transformation $[2,7,8]$ and its treatment with intravascular laser radiation of blood (ILRB) is quite effective. While treating ulcer of stomach we may think about similarity of mechanism of photo-dynamic therapy and ILRB [6.11]. The mechanism of the ILRB therapeutic effects should be detailed.

The key moment in studying the problem is probable possibility to use ILRB for precancer therapy.Thus it is necessary to define the primary acceptors of light photon. The "fate" of photon in starting the molecular, cellular, tissue, organ and organism reactions should be defined.

Indeed, the comparison of the haemoglobins absorption spectra with the spectra of light acting on different functions of an organism, including the cell composition of blood, indicates the maxima et the wavelength near $630 \mathrm{~nm}$, and also at 420,580 , and $760 \mathrm{~nm}$ in all the spectra, which coincide with the known absorption bands of endogene porphyrins $[4,5,9]$, what prooves the plansibility of our assumptions. In order to determine the primary acceptors of light we have measured the absorption and fluorescence spectra of whole blood and its components being in different physiological states. In Fig.1 the absorption spectra of the venous whole blood being in the normal state (1) and while hypoxie (2) are, represented, also with typical absor ption spectra of the washed erythrocyte smears (3), and of the white blood cells (4). The arrows indicate the positions of maxima in absorptions bands of different blood samples.

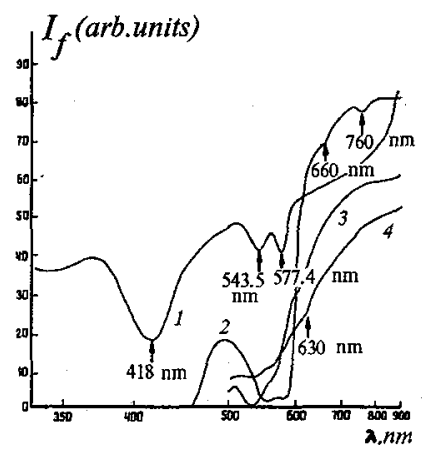

Fig.1

As seen from the absorption spectra (2), (3), and (4), there is a weak absorbtion band having the maximum at the $620-630 \mathrm{~nm}$ wavelength, which coincides with the $\mathrm{He}-\mathrm{Ne}$ laser wavelength and which is located at the wings of strong absorption lines of oxihemoglobine (542 
and $577 \mathrm{~nm}$ ) and of desoxihemoglobine $(569 \mathrm{~nm})$. In this case, when irradiating the blood by $\mathrm{He}-\mathrm{Ne}$ laser from the long-wave side of this absorption band, the fluorescence band has to be observed, which maximum is on the red side of a spectrum. In Fig. 2 the fluorescence spectra of the whole blood (1), plasma (2), and serum (3) are represented, which are obtained by irradiation the samples by He-Ne laser. As seen from these spectra, on the background of the broad unstructured fluorescence band having the maximum at the $710 \mathrm{~nm}$ wavelength and being the same for all three cases, two weak narrow fluorescence bands are observed centred at 645 and $685 \mathrm{~nm}$, which belong to hematoporphyrine or its derivatives.

When irradiating the erythrocyte smears and the white blood cells by the second harmonic of Nd:YAG laser with the $532 \mathrm{~nm}$ wavelength, which coincides with one of the strong absorption bands of porphyrine molecules, we have observed the appearance of narrow dips in fluorescence spectra sited at the $569,580,590,619,635$, and $681 \mathrm{~nm}$ wavelengths related to photomodifications of these molecules. Note, that the analogous narrow dips in fluorescence spectra have been observed by us earlier, when irradiating stomach mucous cells by Nd:YAG laser second harmonic [10].

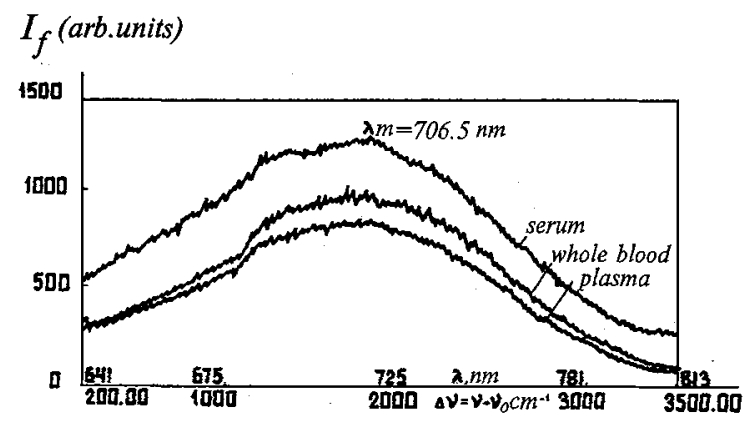

Fig.2

In such a way, the given spectral characteristics testify convincingly to the presence of primary acceptors of photons at the He-Ne laser wavelength based on series of porphyrine molecules. This conclusion allows us to reduce the fast primary dark stages of photochemistry processes of irradiation of blood by visible and near IR light to comparatively well studied photooxida tion processes with participation of porphyrine molecules localized in various biological structures, which lead to generation of active forms of oxigen and accumulation of products of peroxidation of lipoids, and also to direct photoreactivation of antioxidation protection ferments.

In treatmeant of 364 patients with gastric precancer (stomach ulcer with mucosa dysplasia) we used the ILRB in original method [11]. The absolute regression of mucosa dysplasia and close of ulcer are registrated in $49.7 \%$ and $68 \%$ cases accordingly. The contents of athipical cells and mitotic index are reduced from $38,3 \%$ to $9,7 \%$ and from $6,9 \%$ to $2,7 \%$ accordingly.

\section{REFERENCES}

1. Benson R.C., Farrow G.M., Kinsey J.H. et al. Detection and localization of an in situ carcinoma of the bladder with he matoporphyrin derivative. Mayo Clin. Proc. 1982. v.57. p.548555.

2. Carter R.L. Precancerous states. Moscow.:Medicina. 1978.430 pp. 
3. Dougherty T.J.,Potter W.R.,Weishaupt K.R. The structure of the active component of hematoporphyrin derivative. In Andreoni A., Cubeddu R.(Eds) Porphyrins in tumor phototherapy:New York:Plenum Press.1984.p.23-35.

4. Gamaleya N.F.,Shishko E.D.,Yashin Y.V. The sensitivity of cortical human and animal cells to visible light//.Molecular mechanisms of biological action of optic radiation. M.:Nauka. Ed. L.V.Rudin. 1988

5. Karu T.I. Photobiological fundamentals of low-power laser therapy. IEEE J.of Quantum Electronics.1987.v.23. N 10.p.1703-1717.

6. Modyaev V.P., Karpov A.B. et al. Potentialities of low-energy laser radiation in the treatment of precancer of the stomach. Vopr.Oncol. 1991. v.37. N 6. p.731-734.

7. Morson B.,Sobin L.,Grundmann E. et al. Precancerous conditions and epithelial dysplasia in the stomach. J.Clin.Path. 1980. v.33. p.711- 721.

8. Samsonov V.A. Tumors and tumor-like formations of the stomach. Moscow:Medicina. $1989.240 \mathrm{pp}$.

9. Udut V.V.,Prokopjev V.E.,Karpov A.B. et al. Mechanisms and effects of low-energy HeNe lasers radiation on circulating blood. J.de Physique IY. Colloque C7,supplement au J. de Physique III, vol.1, decembre 1991. v.1. p.257-260.

10. Prokopjev V.E.,Udut V.V.,Modyaev V.P. et al. Laser spectrofluorimetric devide for clinical identification of malignancies and thier microscopis diagnosis. Proc. SPIE.,1993,v.1972, p.433-450.

11. Udut V.V.,Prokopjev V.E.,Karpov A.B. et al. Laser radiation in diagnosis and treatment of precarcinoma of the stomach: Theses of reports of the international conference "Lasers in medicine". Tashkent.10-13 October, 1989. 